\title{
Penerapan Pendidikan Karakter Gemar Membaca Melalui Program Literasi di Sekolah Dasar
}

\author{
Silvia Nur Priasti ${ }^{1}$, Suyatno ${ }^{* 2}$ \\ ${ }^{1}$ Department of Primary Teacher Education, $*^{2}$ Department of Education Management \\ Faculty of Teacher Training and Education, Universitas Ahmad Dahlan \\ *Corresponding Author. Email: suyatno@pgsd.uad.ac.id
}

\begin{abstract}
This study aims to find a model for the application of character education for reading fondness through literacy programs. This research is a type of qualitative research with a case study approach. The research subjects consisted of the principal, teachers, and students at SD Negeri Sidareja 01 Cilacap. In collecting data, researchers used instruments in the form of interview guidelines, observation guidelines, and document analysis guidelines. The data analysis technique used is the interactive data analysis technique of Miles and Huberman which consists of data reduction, data presentation, and conclusion drawing. The results showed that character education for reading fondness through the School Literacy Program at SD Negeri Sidareja 01 was carried out through: 1) The habituation phase which includes reading habit for 10-15 minutes and other activities that can build literacy culture and literacy-friendly physical environment conditioning. 2) The development phase which includes the development of literacy skills through various non-academic activities as well as the promotion of the social and affective environment as a model of literate communication and interaction. 3) The learning phase which includes the implementation of learning using a variety of literacy strategies and making schools a literate academic environment through professional development.
\end{abstract}

Abstrak: Penelitian ini bertujuan untuk menemukan model penerapan pendidikan karakter gemar membaca melalui program literasi. Penelitian ini menggunakan pendekatan kualitatif dengan metode studi kasus. Subjek penelitian terdiri dari kepala sekolah, guru, dan siswa di SD Negeri Sidareja 01 Cilacap. Data dikumpulkan dengan menggunakan instrumen pedoman wawancara, pedoman observasi, dan pedoman analisis dokumen. Teknik analisis data yang digunakan yaitu teknik analisis data model interaktif Miles dan Huberman yang terdiri dari reduksi data, penyajian data, dan penarikan kesimpulan. Hasil penelitian menunjukan bahwa pendidikan karakter gemar membaca melalui Program Literasi Sekolah di SD Negeri Sidareja 01 dilaksanakan melalui: 1) Fase pembiasaan yang meliputi pembiasaan membaca selama 10-15 menit dan kegiatan lain yang dapat membangun budaya literasi serta pengondisian lingkungan fisik ramah literasi; 2) Fase pengembangan yang meliputi pengembangan kemampuan literasi melalui berbagai kegiatan non akademis serta pengupayaan lingkungan sosial dan afektif sebagai model komunikasi dan interaksi literat; 3) Fase pembelajaran yang meliputi pelaksanaan pembelajaran menggunakan beragam strategi literasi dan pengupayaan sekolah sebagai lingkungan akademis yang literat melalui pengembangan keprofesian.

\section{Article History}

Received: 09-12-2020

Revised: 07-03-2021

Accepted: 20-04-2021

Published: 07-06-2021

\section{Key Words:}

Character Building,

Reading Fondnes,

Literacy.

\section{Sejarah Artikel}

Diterima: 09-12-2020

Direvisi: 07-03-2021

Disetujui: 20-04-2021

Diterbitkan: 07-06-2021

\section{Kata Kunci: \\ Pendidikan Karakter, Gemar Membaca, Literasi.}

How to Cite: Priasti, S., \& Suyatno, S. (2021). Penerapan Pendidikan Karakter Gemar Membaca Melalui Program Literasi di Sekolah Dasar. Jurnal Kependidikan: Jurnal Hasil Penelitian dan Kajian Kepustakaan di Bidang Pendidikan, Pengajaran dan Pembelajaran, 7(2), 395-407. doi:https://doi.org/10.33394/jk.v7i2.3211 


\section{Pendahuluan}

Pendidikan merupakan sarana penting untuk meningkatkan kualitas sumber daya manusia. Salah satu tujuan penting pendidikan adalah melahirkan manusia yang berkarakter. Untuk melahirkan manusia yang berkarakter dibutuhkan proses dalam jangka panjang, terlebih proses yang dilakukan selama pendidikan dari jenjang pendidikan dasar hingga menengah (Dekawati, 2020; Nitte \& Bulu, 2020; Wijayanti, 2018). Pemerintah Indonesia telah berupaya menerapkan pendidikan karakter melalui Rencana Pembangunan Jangka Panjang Nasional (RPJPN) tahun 2005-2025, yang di dalamnya ditegaskan bahwa "Pendidikan karakter sebagai landasan untuk mewujudkan visi pembangunan nasional" (Kemdiknas, 2011). Pada awal dicanangkannya pendidikan karakter, terdapat 18 nilai karakter, salah satunya adalah karakter gemar membaca.

Karakter gemar membaca adalah salah satu karakter penting untuk menunjang kemajuan bangsa Indonesia. Hal tersebut dapat dilihat bahwa sebagian besar negara maju memiliki budaya gemar membaca. Purnomo (2018) menjelaskan bahwa berdasarkan sebuah survei mengenai tingkat literasi nasional di dunia yang diikuti oleh 61 negara, tercatat bahwa negara maju seperti Finlandia dan Norwegia untuk tingkat literasinya berada di peringkat 1 dan 2, sedangkan negara maju lainnya yang sangat berpengaruh di dunia seperti Amerika, Jerman dan Inggris berada di peringkat 7, 8 dan 18. Selain itu di Asia terdapat Korea Selatan, Cina, Jepang dan Singapura, masing-masing menduduki peringkat 22, 19, 32 dan 36.

Dalam satu dekade terakhir, pemerintah Indonesia telah berhasil meluaskan akses pendidikan dan memberantas buta aksara. Alasan tersebut dapat dilihat melalui data dari Indeks Aktivitas Literasi Membaca 34 Provinsi yang menjelaskan bahwa sejak tahun 1973 tercatat pencanangan SD Instruksi Presiden (INPRES) yang mana itu adalah salah satu upaya untuk meluaskan akses pendidikan di Indonesia. Begitu pula dengan kasus buta aksara. Berdasarkan pencatatan data statistik dalam rangka 70 tahun kemerdekaan Indonesia (2015), pada tahun 1971 tercatat $39,1 \%$ penduduk Indonesia menyandang buta huruf. Seiring berjalannya waktu tepatnya pada pencatatan di tahun 2014, angka 39,1\% telah berubah menjadi 4,4\% pada tahun 2000 (era reformasi). Angka tersebut menunjukan telah terjadi penyusutan kasus buta aksara ataupun buta huruf di Indonesia (Solihin dkk., 2019).

Namun demikian, keberhasilan pemerintah tersebut belum diimbangi dengan keberhasilan dalam menumbuhkan budaya baca masyarakatnya. Beberapa penelitian menunjukan hasil yang kurang menyenangkan, salah satu di antara penelitian tersebut adalah penelitian yang dilakukan oleh Programe for International Student Assesment (PISA). Berdasarkan survei tersebut, pada tahun 2015 tingkat literasi Indonesia tercatat berada pada posisi ke-64 dari 72 negara. Sedangkan survei Central Connecticut State University memosisikan Indonesia di urutan ke 60 dari 61 negara partisipan (Solihin, 2019). Berdasarkan data-data yang telah tersaji maka dapat diketahui bahwa tingkat literasi membaca masyarakat Indonesia masih tergolong rendah. Kondisi tersebut mengindikasikan bahwa penerapan pendidikan karakter gemar membaca belum terlaksana dengan baik.

Rendahnya minat baca pada seseorang dapat membawa dampak buruk, baik bagi dirinya sendiri maupun bagi masyarakat. Pitaloka (2018) mengungkapkan bahwa rendahnya minat baca dapat membawa dampak buruk bagi individu itu sendiri dan bagi bangsa. Adapun dampak buruk bagi individu yaitu kurang menguasai dalam suatu bidang ilmu, hingga menurunnya prestasi khususnya pada peserta didik. Sedangkan dampak buruk yang dapat ditimbulkan bagi bangsa yaitu dalam persaingan global negara akan selalu tertinggal dengan negara-negara lain. Dengan demikian, lembaga pendidikan dituntut menjadi agen dalam meningkatkan karakter gemar membaca siswa. Program literasi merupakan salah satu 
program yang telah dicanangkan oleh pemerintah dalam rangka meningkatkan karakter gemar membaca siswa.

Pendidikan karakter adalah pendidikan yang mengajarkan moral dan kepribadian peserta didik (Fadillah \& Khorida, 2013; Sumarsih \& Zakaria, 2020). Selanjutnya, Gunawan (2012) berpendapat bahwa pendidikan karakter bertujuan untuk membentuk karakter bangsa Indonesia yang sesuai dengan nilai-nilai yang terkandung dalam Pancasila. Menurut Sari (2018), gemar membaca adalah kegemaran atau kesukaan terhadap suatu bacaan untuk memperoleh berbagai informasi dan wawasan. Dalam pelaksanaannya pendidikan karakter gemar mebaca dipengaruhi oleh beberapa faktor. Laksmi dalam Mudzanatun (2018) mengungkapkan bahwa minat baca seseorang dapat dipengaruhi oleh dua faktor, yaitu faktor internal yang dapat berupa besarnya rasa keingintahuan ataupun tuntutan kebutuhan seperti persiapan penelitian, persiapan ujian, persiapan presentasi dan lain sebagianya, serta faktor eksternal yang dapat berupa faktor sosial di mana lingkungan sekitar yang turut mendukung dan adanya bahan bacaan yang menarik.

Program penerapan karakter gemar membaca bertujuan agar masyarakat Indonesia dapat menjadi masyarakat yang memiliki kesenangan atau kegemaran membaca. Oleh karena itu, diperlukan suatu indikator untuk dapat mengetahui keberhasilannya. Gemar membaca di sekolah dapat dikatakan berhasil apabila memenuhi beberapa indikator. Indikator keberhasilan penerapan karakter gemar membaca bagi siswa di antaranya adalah pemanfaatan perpustakaan sebagai sumber belajar siswa (Ramly dalam Perpusnas, 2014).

Gerakan literasi sekolah (GLS) merupakan suatu usaha yang bersifat partisipatif, yang mana gerakan tersebut akan berhasil apabila terdapat kerja sama yang baik dari berbagai elemen, baik itu elemen masyarakat, elemen tenaga kependidikan maupun elemen pemerintah. Tujuan adanya gerakan tersebut yaitu untuk dapat mewujudkan warga sekolah yang literat sepanjang hayat. Salah satu upaya untuk mewujudkan tujuan tersebut yaitu melalui pembiasaan membaca selama 15 menit sebelum dimulainya pembelajaran. (Satgas GLS Kemendikbud. 2018). Kondisi tersebut sejalan dengan dengan pernyataan Sobirin dan Susapti (2018) bahwa literasi dipercaya sebagai gerbang utama untuk membuka segala ilmu melalui berbagai bidang studi. Siswa dengan kemampuan literasi yang baik cenderung memiliki kepercayaan diri yang tinggi dan prestasi belajar yang lebih baik (Zulfahita, Husna, \& Mulyani, 2020).

Sebagai salah satu lembaga pendidikan dasar di Indonesia yang terletak di Kabupaten Cilacap, SD Negeri Sidareja 01 merupakan salah satu sekolah dasar yang turut menjalankan Gerakan Literasi Sekolah (GLS) sesuai dengan ketentuan pemerintah. Selain anjuran dari pemerintah, pelaksanaan gerakan literasi sekolah di SD Negeri Sidareja 01 tersebut juga menjadi program sekolah yang bertujuan untuk meningkatkan kemampuan literasi, khususnya literasi membaca pada peserta didik.

Dengan terselenggaranya program literasi di SD Negeri Sidareja 01 Kabupaten Cilacap, Propinsi Jawa Tengah dan fasilitas yang mendukung, hal itu dapat menumbuhkan karakter gemar membaca pada peserta didik. Kondisi tersebut dapat dilihat melalui kemampuan yang cukup baik pada sebagian besar peserta didik dalam menjawab pertanyaan dan mengisi waktu-waktu luang mereka dengan membaca ketika menanti kedatangan guru dalam rangka pembelajaran luar jaringan internet. Adapun bukti tingginya minat baca peserta didik ketika di sekolah yaitu seringnya SD Negeri Sidareja 01 meraih juara berbagai perlombaan, baik perlombaan akademik maupun non akademik, serta banyaknya jumlah pengunjung perpustakaan pada setiap bulan sebelum kegiatan belajar mengajar dirumahkan karena pandemi Covid-19. 
Adapun tujuan penelitian ini adalah untuk menemukan model penerapan pendidikan karakter gemar membaca melalui program literasi pada peserta didik di SD Negeri Sidareja 01. Hasil penelitian ini diharapkan dapat memberikan wawasan ilmiah kepada pemangku jabatan, praktisi pendidikan dan khususnya para guru di sekolah dasar dalam melaksanakan program literasi untuk membangun karakter gemar memaca pada peserta didik.

\section{Metode Penelitian}

Penelitian ini menggunakan pendekatan kualitatif dengan metode studi kasus (Creswell, 2013). Penelitian kualitatif adalah penelitian yang diambil dari kondisi objek yang alamiah dan bersifat mendalam, serta lebih menekankan makna dari pada generalisasi dengan tujuan untuk menggambarkan suatu realitas yang kompleks (Gomm et al., 2000; Noor, 2008; Sugiyono, 2015). Sedangkan menurut Arikunto (2013) penelitian dengan metode studi kasus adalah penelitian yang dilakukan pada suatu lembaga, organisasi ataupun gejala tertentu secara intensif, terperinci dan mendalam.

Subjek dalam penelitian ini yaitu kepala sekolah sebagai penanggung jawab terselenggaranya program literasi sekolah, perwakilan guru wali kelas atas dan guru wali kelas bawah sebagai pembimbing kegiatan literasi sekolah kaitannya dengan karakter gemar membaca, serta peserta didik kelas 3 dan 5 di SD Negeri Sidareja 01, Kabupaten Cilacap, Propinsi Jawa Tengah.

Teknik pengumpulan data dalam peneltian kualitatif dilakukan pada kondisi alamiah, sumber data primer dan lebih banyak pada observasi, wawancara mendalam serta dokumentasi. Oleh karena itu, dalam penelitian ini teknik pengumpulan yang digunakan adalah observasi, wawancara dan dokumentasi (Denzin \& Lincoln, 2011; Yin, 2003). Dalam melakukan wawancara dibantu dengan pedoman penelitian agar wawancara lebih terarah. Demikian juga dalam melakukan pengamatan dan dokumentasi merujuk pada pedoman observasi dan dokumentasi yang telah dibuat sebelumnya. Model analisis data yang digunakan dalam penelitian ini yaitu model temuan Miles, Huberman, dan Saldana (2014) yang dinamakan model interaktif (interactive model).

\section{Hasil Penelitian dan Pembahasan}

Berdasarkan analisis data induktif interaktif, tema-tema hasil penelitian terbentuk berdasarkan kode-kode yang ditemukan. Tema-tema yang ditemukan kemudian dibedakan sesuai dengan keperluan dalam menjawab rumusan masalah penelitian yang telah diajukan.

\section{Acuan Penerapan Pendidikan Karakter Gemar Membaca}

Pendidikan karakter gemar membaca melalui program literasi sekolah yang diimplementasikan di SD Negeri Sidareja 01 berlandaskan pada visi-misi serta program sekolah. Selain visi-misi dan program sekolah, peraturan dari pemerintah juga menjadi dasar penerapan pendidikan karakter gemar membaca melalui program literasi di SD Negeri Sidareja 01. Sebagaimana diketahui bahwa landasan yang digunakan oleh pemerintah dalam mencanangkan pendidikan karakter di negara ini yaitu berdasarkan pada UU Nomor 20 tahun 2003 tentang Sistem Pendidikan Nasional yang menegaskan bahwa: "Pendidikan nasional berfungsi mengembangkan kemampuan dan membentuk watak serta peradaban bangsa yang bermartabat dalam rangka mencerdaskan kehidupan bangsa, bertujuan untuk berkembangnya potensi peserta didik agar menjadi manusia yang beriman dan bertakwa kepada Tuhan Yang Maha Esa, berakhlak mulia, sehat, berilmu, cakap, kreatif, mandiri dan menjadi warga negara yang demokratis serta bertanggung jawab"

Pelaksanaan program literasi di SD Negeri Sidareja 01 berlandaskan dari peraturan pemerintah, visi-misi dan program sekolah. Sebagaimana yang dituturkan oleh kepala 
sekolah dalam wawancara: "Itukan ada aturan dari pemerintah itu. Iya tertulis, ada di visimisi sekolah (SD Negeri Sidareja 01) juga. Terus itu juga masuk program sekolah.” (Wawancara KS, 30 Juli 2020). Pernyataan kepala sekolah tersebut diperkuat dengan pendapat dari wali kelas 5A yang mengatakan bahwa penerapan pendidikan karakter gemar membaca melalui program literasi berlandaskan pada aturan dari pemerintah, visi-misi dan program sekolah. "Betul dari pemerintah (peraturan pemerintah). Visi-misi (SD Negeri Sidareja 01) ada, jadi visi misi kami kemarin ada perubahan yang intinya itu lebih menekankan pada karakter, diantaranya gemar membaca." (Wawancara WK 5 A, 30 Juli 2020). Tujuan penerapan pendidikan karakter gemar membaca melalui program literasi di SD Negeri Sidareja 01 yaitu untuk membentuk karakter gemar membaca. Hal tersebut sesuai dengan pernyataan seorang guru: "Meningkatkan kemampuan literasi gemar membaca, menumbuhkan minat baca warga sekolah, ya meningkatkan gemar membaca lah ya, intinya itu sih." (Wawancara WK 5 A, 30 Juli 2020).

Peraturan tersebut selaras dengan landasan pencanangan gerakan literasi sekolah dari pemerintah yang salah satunya yaitu Permendikbud Nomor 23 tahun 2015 tentang Penumbuhan Budi Pekerti yang membahas mengenai membaca buku non pelajaran selama 15 menit sebelum pelajaran dimulai. Berdasarkan kedua landasan hukum di atas maka dapat diketahui bahwa sejatinya pendidikan karakter dan gerakan literasi sekolah memiliki tujuan yang senada. Dalam Satgas GLS Kemendikbud (2018), dijelaskan bahwa gerakan literasi sekolah bertujuan untuk membentuk warga sekolah yang yang literat dalam hal: baca-tulis, numerasi, sains, digital, finansial, budaya, dan kewargaan. Seperti halnya tujuan gerakan literasi sekolah tersebut, pendidikan karakter juga memiliki tujuan yang serupa sebagaimana yang tercantum dalam Kemdiknas (2011) bahwa pendidikan karakter bertujuan untuk dapat mengembangkan potensi dalam segala aspek yang dimiliki oleh peserta didik agar dapat menjiwai karakter yang terpuji.

\section{Fase Pembiasaan}

Fase pembiasaan merupakan langkah paling sederhana dalam pelaksanaan program literasi. Aktivitas dalam fase pembiasaan ini terbagi menjadi dua strategi yaitu pembiasaan membaca buku selama 10-15 menit serta kegiatan lain yang dapat membangun budaya literasi dan pengondisian fisik ramah literasi. Pada aktivitas pembiasaan membaca buku selama 10-15 menit serta kegiatan lain, sasaran utama kegiatan pembiasaan adalah membaca buku selama 10-15 menit. Dengan menjalankan kebiasaan membaca buku selama 10-15 menit sebelum pembelajaran terhadap peserta didik, diharapkan kegiatan tersebut dapat menumbuhkan minat baca mereka, sehingga dapat membentuk karakter gemar membaca. Kondisi tersebut sesuai dengan aturan Satgas GLS Kemendikbud (2018) yang menyatakan bahwa pembiasaan membaca buku selama 10-15 menit bertujuan untuk menumbuhkan minat baca dalam diri warga sekolah. Ketika minat baca telah tumbuh, maka memunculkan karakter gemar membaca bukanlah suatu hal yang sulit. Selain kegiatan membaca buku selama 10-15 menit sebelum pembelajaran, sekolah juga menjalankan kebiasaan lainnya untuk menumbuhkan minat baca pada peserta didik. Berbagai kegiatan tersebut yaitu tanya jawab ketika berbaris sebelum masuk ke dalam kelas, menghafalkan surat pendek dalam Al-Qur'an, Asma'ul Husna serta Pancasila. Melalui wawancara, kepala sekolah menjelaskan:

"Ada tanya jawab pada saat baris sebelum masuk kelas, terkadang perkalian (soal perkalian) kalau yang kelas 5 itu biasanya kami mengadakan di sana ada soal yang kecil-kecillah (soal sederhana), nanti setiap siswa ditanya. Kita masuk jam 7, ada literasi membaca 10-15 menit. Kita masuk kemudian berdoa, setelah berdoa dilanjut menghafal surat pendek (surat pendek dalam Al-Qur'an), terus Asma'ul Husnanya (menghafalkan Asma'ul Husna), baru yang literasi membaca 10-15 menit. Kalau yang 
kelas kecil ya Pancasila (menghafalkan Pancasila), kalau kelas tinggi sudah tidak menghafalkan Pancasila" (Wawancara KS, 30 Juli 2020).

Sejatinya untuk menerapkan minat baca tidaklah harus melalui kegiatan membaca buku selama 10-15 menit, tetapi juga dapat diterapkan melalui upaya pembiasaan lainnya seperti kegiatan menghafal, tanya jawab soal, merangkum dan menceritakan kembali. Dengan adanya kegiatan tersebut maka dapat mendorong seseorang untuk membaca, walaupun tidak selama 10 atau 15 menit. Kondisi tersebut sejalan dengan pendapat Suyatno dkk. (2019) yang mengungkapkan bahwa untuk menanamkan suatu nilai yang baik maka diperlukan pembiasaan, dengan demikian mereka akan terbiasa untuk melakukannya meskipun mereka berada di luar tempat di mana proses pembiasaan tersebut telah dilakukan. Lingkungan fisik sekolah adalah lingkungan yang pertama kali terlihat oleh warga sekolah. Menurut Beers, dkk dalam Satgas GLS Kemendibud (2018), untuk dapat melaksanakan pembelajaran yang baik maka diperlukan lingkungan yang nyaman dan mendukung. Pernyataan tersebut sejalan dengan pendapat Muslih (2016) yang menjelaskan bahwa hal yang paling berpengaruh dalam proses belajar dan perkembangan anak adalah lingkungan. Oleh karena itu, sekolah perlu mengatur lingkungannya sedemikian rupa agar dapat mencerminkan sekolah dengan budaya yang literat. Upaya pengaturan lingkungan ini dapat dilakukan dengan berbagai cara seperti menyediakan fasilitas pendukung literasi dan memajang berbagai karya peserta didik di area sekolah. Selaras dengan pendapat tersebut, upaya yang dilakukan SD Negeri Sidareja 01 dalam mengondisikan lingkungan fisik yang literat yaitu dengan cara menyediakan fasilitas yang mendukung program literasi seperti perpustakaan, pojok baca, dan area baca luar ruangan. Selain itu sekolah juga memajang berbagai karya peserta didik seperti gambar, puisi di kelas ataupun majalah dinding sekolah dengan tujuan untuk memperindah lingkungan sekolah dengan nuansa literasi.

Berdasarkan hasil wawancara dengan peserta didik kelas 5A, ia mengungkapkan bahwa dirinya pernah menggunakan berbagai fasilitas pendukung program literasi yang ada di sekolah seperti perpustakaan, pojok baca, dan area baca luar ruangan. Dengan demikian dapat diketahui bahwa selain perpustakaan dan pojok baca, SD Negeri Sidareja 01 juga memiliki area baca luar ruangan sebagai fasilitas pendukung program literasi.

“'Iya seringnya ketika 'N' istirahat itu ' $N$ ' ke perpus dan membaca bukunya. Ya buku apa aja, pinjam buku. Pernah juga membaca di tempat duduk itu yang di depan perpustakaan (area baca luar ruangan). Pojok baca sering dipakai juga." (Wawancara PD Kelas 5 A, 2 Agustus 2020).

\section{Fase Pengembangan}

Fase pengembangan merupakan tindak lanjut dari fase pembiasaan. Aktifitas dalam fase pengembangan terbagi menjadi dua strategi yaitu pengembangan kemampuan literasi melalui berbagai kegiatan non akademis serta pengupayaan lingkungan sosial dan afektif sebagai model komunikasi dan interaksi literat. Menurut Satgas GLS Kemendikbud (2018) aktivitas pengembangan kemampuan literasi dapat dilakukan melalui berbagai kegiatan non akademis seperti menulis sinopsis, berdiskusi mengenai buku yang telah dibaca, penyelenggaraan ekstrakurikuler dan jadwal wajib kunjung perpustakaan (jam literasi).

Aktivitas pengembangan kemampuan literasi melalui berbagai kegiatan non akademis yang dijalankan oleh SD Negeri Sidareja 01 yaitu melalui berbagai macam kegiatan ekstrakurikuler. Berdasarkan hasil wawancara, kepala sekolah menjelaskan bahwa:

"Kami (pihak sekolah) juga mengadakan kegiatan ekstrakurikuler. Banyak macamnya.

Kalau yang literasi puisi dan mendongeng." (Wawancara KS, 30 Juli 2020).

Jawaban kepala sekolah tersebut juga turut didukung dengan pernyataan wali kelas 5A dan wali kelas 3A. Dalam wawancara, wali kelas 5A mengatakan bahwa "Ekstrakurikuler di sini 
ada banyak. Kalau tentang literasi paling itu mendongeng, puisi, biasanya saya yang melatih." (Wawancara WK 3 A, 7 Agustus 2020). Sedangkan wali kelas 3A juga berpendapat yang serupa dengan wali kelas 5A (Wawancara WK 5A, 30 Juli 2020).

Tidak hanya eksktrakurikuler, dalam melakukan pengembangan kemampuan literasi SD Negeri Sidareja 01 juga mengadakan kegiatan wajib kunjung perpustakaan. Kondisi tersebut dapat terlihat melalui hasil observasi dan dokumentasi yang dilakukan oleh peneliti. Dalam hasil observasi pada hari pertama hingga hari ke enam ditemukan hasil yang sepadan yang menunjukan bahwa di SD Negeri Sidareja 01 terdapat jadwal wajib kunjung perpustakaan. pada jadwal tersebut tercantum hari wajib kunjung perpustakaan yang berbeda pada setiap jenjang kelas. Selain itu peneliti juga menemukan daftar pengunjung perpustakaan. Pada sisi lain, hasil dokumentasi semakin memperkuat hasil observasi yang dilakukan oleh peneliti.

Senada dengan temuan penelitian ini, Inriyani dkk. (2017) menjelaskan bahwa kegiatan eksktrakurikuler merupakan program kegiatan belajar mengajar di luar jam pembelajaran akademis dengan tujuan untuk meningkatkan kreativitas, bakat serta menumbuhkan semangat para peserta didik dalam hal pengabdian pada masyarakat. Selain penyelenggaraan kegiatan ekstrakurikuler, sekolah juga menjadwalkan kunjungan wajib ke perpustakaan bagi peserta didik. Kegiatan tersebut diharapkan dapat membantu sekolah dalam menumbuhkan minat baca pada peserta didik. Tidak dapat dipungkiri, adanya fasilitas perpustakaan memang sangat membantu dalam menunjang aktivitas pembelajaran di sekolah. Sebagaimana yang diungkapkan oleh Darmono dalam Imanugroho dan Ganggi (2019), bahwa perpustakaan sekolah sebagai salah satu sarana pendidikan penunjang kegiatan belajar peserta didik yang memegang peranan yang sangat penting dalam dalam memacu tercapainya tujuan pendidikan di sekolah. Selain itu, adanya jadwal wajib kunjung perpustakaan juga merupakan salah satu indikator keberhasilan penerapan karakter gemar membaca. Seperti yang dituturkan oleh Ramli dalam Perpusnas (2014), bahwa salah satu indikator keberhasilan penerapan karakter gemar membaca yaitu terdapatnya jadwal pengunjung perpustakaan.

Sementara itu dalam pengupayaan lingkungan sosial dan afektif sebagai model komunikasi dan interaksi literat, SD Negeri Sidareja 01 sering memberikan pengakuan prestasi yang diraih oleh peserta didik. Berdasarkan hasil wawancara, kepala sekolah mengatakan bahwa ketika ada peserta didik yang berhasil memenangkan lomba, salah satu dukungan yang pihak sekolah lakukan yaitu dengan cara mengakui terhadap prestasi yang diraih oleh peserta didik tersebut. Pengakuan sekolah terhadap prestasi yang diraih oleh peserta didik diwujudkan melalui pemberian penghargaan. "Sekolah memberi penghargaan piala, piagam, uang pembinaan dari sekolah." (Wawancara KS, 30 Juli 2020). Pernyataan kepala sekolah tersebut didukung oleh pendapat wali kelas 5A, yang mengunkapkan bahwa "Ya dari sekolah sangat mendukung. Iya, ada penghargaannya. Jadi kan salah satunya yang juara mendongeng itu, bercerita, maaf lomba bercerita. Jadi bisa dapat piala, dapat uang saku seperti" (Wawancara WK 5 A, 30 Juli 2020).

Temuan ini sesuai dengan teori dari Beers, dkk dalam Satgas GLS Kemendikbud (2018) yaitu upaya pembentukan lingkungan sosial dan afektif sebagai model komunikasi dan interaksi literat dapat dikembangkan melalui pengakuan prestasi yang dicapai oleh peserta didik dalam berbagai aspek, baik itu akademis maupun non akademis. Pengakuan prestasi yang dilakukan oleh SD Negeri Sidareja 01 yaitu melalui pemberian penghargaan yang dapat berupa piala, piagam ataupun uang pembinaan pada peserta didik yang memenangkan perlombaan. Pemberian penghargaan pada peserta didik ini penting adanya. Hamalik dalam Syahrul (2017) mengungkapkan bahwa pemberian penghargaan dalam 
belajar dapat menjadikan motivasi bagi seseorang untuk dapat lebih giat belajar dalam kondisi apapun.

\section{Fase Pembelajaran}

Fase pembelajaran merupakan langkah yang paling akhir dalam pelaksanaan program literasi. Sebagai langkah terakhir, fase pembelajaran merupakan upaya mendalam penanaman pelaksanaan program literasi. Seperti dua fase sebelumnya, dalam fase pembelajaran ini juga terdapat dua strategi yaitu pelaksanaan pembelajaran dengan beragam strategi literasi dan pengupayaan sekolah sebagai lingkungan akademis yang literat melalui pengembangan profesional tentang literasi pada tenaga pendidik di sekolah.

Seperti pada umumnya, strategi literasi merupakan strategi pembelajaran untuk meningkatkan kemampuan literasi pada peserta didik. Hal tersebut tercermin dalam buku Strategi Literasi Dalam Pembelajaran di Sekolah Menengah Pertama (Satgas GLS Kemendikbud, 2018), yang mengungkapkan bahwa penggunaan strategi literasi dalam pembelajaran bertujuan untuk membangun pemahaman, keterampilan menulis serta komunikasi secara mendalam pada peserta didik. Sebagaimana diketahui bahwa guru di SD Negeri Sidareja 01 senantiasa menggunakan beragam strategi pada pelaksanaan pembelajaran. Beragam strategi tersebut diterapkan melalui beberapa metode pembelajaran seperti menjelaskan materi, meminta peserta didik untuk membaca, merangkum, menceritakan kembali mengenai materi yang telah dibaca, melakukan tanya jawab mengenai materi yang telah dipelajari serta memberi video pembelajaran dan tugas membaca pada peserta didik.

Berdasarkan hasil observasi hari pertama sampai hari kedua yang dilakukan di kelas 5A dengan hasil observasi hari ketiga sampai hari keempat pada kelas 3A, ditemukan hasil yang sama yaitu bahwa guru senantiasa menggunakan beragam strategi pembelajaran. Beragam strategi tersebut dilaksanakan melalui berbagai metode, seperti menjelaskan materi/ teks secara klasikal, mengarahkan peserta didik untuk membaca dengan cara ditunjuk ataupun suka rela, menulis kembali tentang materi yang telah dijelaskan, menceritakan kembali mengenai materi yang baru saja dijelaskan, mengadakan tanya jawab soal ataupun memberikan video pembelajaran untuk disimak oleh peserta didik ketika di rumah. Sedangkan pada hasil observasi gabungan kelas1A dan 1B yang dilaksanakan pada hari ke lima hingga hari ke enam, peneliti menumukan hasil yang berbeda dengan hasil observasi pada kelas-kelas sebelumnya yang berlangsung pada pada hari pertama sampai hari ke empat. Pada observasi hari ke lima hingga hari ke enam dapat ditemukan bahwa strategi yang dilakukan oleh guru pada kegiatan belajar mengajar di kelas 1 pada awal semester masih sangat sederhana. Strategi terebut dilaksanakan melalui metode seperti pengenalan huruf/ abjad serta mengajari cara mengeja bacaan pada peserta didik. Selain itu, guru juga memberikan video pembelajaran untuk disimak oleh peserta didik ketika di rumah.

Berdasarkan hasil wawancara dengan wali kelas 5A, Wk juga mengungkapkan pendapatnya mengenai metode pembelajaran yang digunakan.

"Kalau kelas kami (kelas tinggi, terutama kelas 5 A) tidak, kami membacanya bergantian. Jadi apa ya namanya, estafet anak satu ke anak dua dan itu ngga kita (guru) tunjuk, jadi otomatis jadi mereka ikut nyimak. Karena kalau kelas tinggi membaca lantang kayanya sudah ngga cocok. Itu (tugas membaca) juga pernah kami laksanakan. Jadi halaman ini silahkan kalian baca, setelah itu tutup bukunya, saya beri pertanyaan, sejauh mana sih daya serap (memahami materi) anak-anak. Iya merangkum juga." (Wawancara Wk 5A, 30 Juli 2020).

Ungkapan wali kelas 5A tersebut dilengkapi lagi oleh penjelasan wali kelas $3 \mathrm{~A}$, dalam hasil wawancara dia menjelaskan bahwa metode pembelajaran yang kerap digunakan yaitu 
meminta anak untuk membaca materi sebelum memulai pembelajaran, merangkum dan memutar video pembelajaran pada peserta didik.

Hasil ini sejalan dengan pendapat Yaumi (2014) yang menjelaskan bahwa untuk membangkitkan semangat baca para peserta didik dapat dilakukan dengan cara memberikan penugasan membaca dan menulis kepada siswa, memberi umpan balik terhadap hasil bacaan dan tulisan siswa, mendiskusikan hasil bacaan siswa dalam forum kelas, dan memberikan kesempatan peserta didik yang lain untuk memberi tanggapan.

Selanjutnya, untuk menunjang kegiatan pembelajaran dengan baik, guru juga menggunakan beragam literatur pembelajaran. Berbagai literatur tersebut yaitu LKPD, buku paket, BSE/ buku guru dan peserta didik, ensiklopedia, surat kabar serta artikel dari internet. Seluruh kondisi tersebut sesuai dengan pernyataan dari Satgas GLS Kemendikbud (2018) yang menyatakan bahwa guru diharapkan menggunakan berbagai strategi literasi dalam melaksanakan pembelajaran pada semua mata pelajaran. Pelaksanaan strategi literasi didukung dengan penggunaan ragam teks (cetak/ visual/ digital) atau informasi lain di luar buku pelajaran. Selain itu, kegiatan pembelajaran dengan menggunakan referensi juga merupakan salah satu indikator keberhasilan penerapan karakter gemar membaca. Seperti yang dijelaskan oleh Ramly dalam Perpusnas (2014) bahwa indikator keberhasilan penerapan pendidikan karakter gemar membaca yaitu terdapatnya jadwal wajib kunjung perpustakaan, saling tukar bacaan, dan pembelajaran yang memotivasi peserta didik.

Untuk membangun lingkungan akademis yang mendukung literasi, SD Negeri Sidareja 01 mengupayakan melalui pengembangan keprofesian. Oleh karena itu, SD Negeri Sidareja 01 senantiasa mendukung para tenaga pendidiknya untuk mengikuti berbagai acara atau forum seperti workshop, pelatihan, bimbingan teknis (Bimtek) ataupun kegiatan serupa yang bertujuan untuk meningkatkan pemahaman, pelaksanaan dan keterlakasanaan dari program literasi sekolah. Sebagaimana ungkapan dari kepala sekolah:

"Ada Bimtek, kebetulan tempatnya di sini (SD Negeri Sidareja 01). Nggak hanya itu, kita juga sering mengirim guru untuk Diklat, workshop. Iya jadi itu (Bimtek) membahas tentang kurikulum-13 (kurikulum 2013), sama literasi juga. Jadi literasi itu membahas tentang bagaimana caranya menerapkan literasi, membaca 15 menit sebelum pelajaran" (Wawancara KS, 30 Juli 2020).

Selaras dengan kondisi tersebut, Beers dkk dalam Satgas GLS Kemendikbud (2018) juga mengungkapkan pendapatnya mengenai strategi pelaksanaan program literasi sekolah yaitu untuk membangun lingkungan akademis yang literat, sekolah perlu memberi kesempatan pada guru dan staf kependidikan untuk dapat mengikuti program pelatihan yang bertujuan meningkatkan pemahaman mengenai program literasi sekolah.

Secara umum, terdapat tiga temuan penting dalam penelitian ini, yaitu: pertama, Pengembangan karakter gemar membaca membutuhkan pembiasaan. Lickona (2013) menyebutkan bahwa penanaman karakter kepada anak membutuhkan kegiatan yang dilakukan secara berulang-ulang. Dalam konteks karakter gemar membaca, maka seorang anak harus dibiasakan dengan program-program yang dilakukan secara berulang-ulang setiap hari. Inti pembiasaan adalah pengulangan (Cahyaningrum, Sudaryanti, \& Purwanto, 2017). Proses ini lama kelamaan akan menjadi karakter gemar membaca. Karakter pada hakikatnya merupakan sekumpulan kebiasaan yang terkoordinasi (Hendriana \& Jacobus, 2017). Temuan ini juga menguatkan beberapa penelitian sebelumnya bahwa pembiasaan merupakan salah satu metode yang tepat untuk membentuk karakter siswa (Andiarini \& Nurabadi, 2018; Mardlotillah, 2013). Dengan pembiasaan maka akan terbentuk disiplin (Ihsani, Kurniah, \& Suprapti, 2018). Kedua, pengembangan karakter membaca membutuhkan dukungan kegiatan-kegiatan yang bersifat non-akademis dan lingkungan yang literat. Lingkungan 
merupakan segala aspek baik yang bersifat materiil maupun stimulu yang berasal dari dalam dan luar individu, baik yang bersifat fisik, psikis, dan sosio-kultural (Soemanto, 2003). Ramdhani (2017) menyebutkan bahwa lingkungan memberikan pengaruh dalam membentuk karakter siswa. Oleh karena itu, jika di sekolah terbentuk lingkungan baik yang berupa fisik, psikis, mapun sosio-kultural yang terkait dengan gemar membaca maka kondisi tersebut akan mempengaruhi kebiasaan dan karakter membaca siswa. Sekolah perlu mengupayakan lingkungan yang literat baik dari segi perencanaan dan pelaksanaan program literasi. Sekolah sebaiknya memberikan alokasi waktu yang cukup banyak untuk pembelajaran literasi (Teguh, 2020). Ketiga, pengembangan karakter membaca membutuhkan strategi pembelajaran yang berorientasi pada budaya literat dan penerapan strategi pembelajaran yang interaktif dan konstruktivis. Temuan penelitian ini juga menjelaskan bahwa fase terakhir dalam penerapan pendidikan karakter gemar membaca melalui program literasi sekolah adalah fase pembelajaran.

Fase pembelajaran merupakan langkah yang paling akhir dalam pelaksanaan program literasi. Sebagai langkah terakhir, fase pembelajaran merupakan upaya mendalam penanaman pelaksanaan program literasi. Dalam fase pembelajaran ini juga terdapat dua strategi yaitu pelaksanaan pembelajaran dengan beragam strategi literasi dan pengupayaan sekolah sebagai lingkungan akademis yang literat melalui pengembangan profesional tentang literasi pada tenaga pendidik di sekolah. Pada tahap ini, sekolah perlu menyelenggarakan berbagai kegiatan untuk membentuk minat baca dan meningkatkan kecakapan literasi melalui bukubuku pengayaan dan buku teks pelajaran. Misalnya, kegiatan pembinaan kemampuan membaca, menulis cerita, dan mengintegrasikan kegiatan literasi dalam tahapan pembelajaran (Batubara \& Ariani, 2018; Faizah dkk., 2016).

\section{Kesimpulan}

Kesimpulan yang diperoleh dari penelitian ini menunjukan bahwa pendidikan karakter gemar membaca melalui program literasi sekolah di SD Negeri Sidareja 01 dilaksanakan melalui tiga fase yaitu:

1) Fase pembiasaan yang meliputi pembiasaan membaca selama 10-15 menit dan kegiatan-kegiatan yang dapat membangun budaya literasi serta pengondisian lingkungan fisik ramah literasi;

2) Fase pengembangan yang meliputi pengembangan kemampuan literasi melalui berbagai kegiatan non akademis serta pengupayaan lingkungan sosial dan afektif sebagai model komunikasi dan interaksi literat;

3) Fase pembelajaran yang meliputi pelaksanaan pembelajaran menggunakan beragam strategi literasi dan pengupayaan sekolah sebagai lingkungan akademis yang literat melalui pengembangan keprofesian.

\section{Saran}

Berdasarkan temuan penelitian ini disarankan kepada kepala sekolah tentang pentingnya program gerakan literasi sekolah dalam meningkatkan karakter gemar membaca siswa. Agar berhasil, gerakan literasi perlu diterapkan melalui tiga fase yaitu fase pembiasaan, fase pengembangan, dan fase pembelajaran. Dukungan kepemimpinan sekolah sangat menentukan keberhasilan progam tersebut. Selain itu, kepala sekolah dituntut untuk meningkatkan kompetensi para guru, menyiapkan sarana prasarana, dan menciptakan lingkungan sekolah yang literat. 


\section{Daftar Pustaka}

Andiarini, S. E., \& Nurabadi, A. (2018). Implementasi program penguatan pendidikan karakter melalui kegiatan pembiasaan dalam peningkatan mutu sekolah. JAMP: Jurnal Administrasi dan Manajemen Pendidikan, 1(2), 238-244.

Arikunto, S. (2013). Prosedur Penelitian. Jakarta: Rineka Cipta.

Batubara, H. H., \& Ariani, D. N. (2018). Implementasi Program Gerakan Literasi Sekolah di Sekolah Dasar Negeri Gugus Sungai Miai Banjarmasin. JPsd (Jurnal Pendidikan Sekolah Dasar), 4(1), 15-29.

Cahyaningrum, E. S., Sudaryanti, S., \& Purwanto, N. A. (2017). Pengembangan nilai-nilai karakter anak usia dini melalui pembiasaan dan keteladanan. Jurnal Pendidikan Anak, 6(2), 203-213.

Creswell, J. W. (2013). Qualitative inquiry and research design: Choosing among five approaches (3rd ed.). Sage.

Dekawati, I. (2020). The principal's leadership as the effort to build students'character. International Journal of Educational Management and Innovation, 1(2), 109-119.

Denzin, N. K., \& Lincoln, Y. S. (Eds.) (2011). The SAGE handbook of qualitative research. Sage.

Fadillah, M. \& Khorida, L. M. 2013. Pendidikan Karakter Usia Dini. Yogyakarta: Ar ruzz media.

Gomm, R., Hammersley M., \& Foster, P. (Eds. ). (2000). Case study method. Key issues, key texts. Sage.

Gunawan, H. (2012). Pendidikan Karakter: Konsep dan Implementasi. Bandung: Alfabeta

Hendriana, E. C., \& Jacobus, A. (2017). Implementasi pendidikan karakter di sekolah melalui keteladanan dan pembiasaan. JPDI (Jurnal Pendidikan Dasar Indonesia), 1(2), 25-29.

Ihsani, N., Kurniah, N., \& Suprapti, A. (2018). Hubungan metode pembiasaan dalam pembelajaran dengan disiplin anak usia dini. Jurnal Ilmiah Potensia, 3(2), 105-110.

Imanugroho, S. \& Ganggi, R. I. P. (2019). Program Gerakan Literasi Sekolah dalam Menumbuhkan Minat Baca Peserta Didik di SDN Kuripan Lor 01 Kota Pekalongan. Jurnal Ilmu Perpustakaan. 7(2): 71-80.

Inriyani, Y., Wahjoedi, \& Sudarmiatin. (2017). Peran kegiatan Ekstrakurikuler Untuk Meningkatkan Prestasi Belajar IPS. Prosiding Seminar Nasional Mahasiswa Kerjasama Direktorat Jendral Guru dan Tenaga Kependidikan Kemendikbud. Universitas Negeri Malang. Malang. 1

Kemdiknas. (2011). Panduan Pelaksanaan Pendidikan Karakter. Jakarta: Kemdiknas.

Lickona, T. (2013). Pendidikan karakter: Panduan lengkap mendidik siswa menjadi pintar dan baik. Bandung: Nusa Media.

Mardlotillah, F. (2013). Implementasi Kebijakan Sekolah dalam Upaya Pengembangan Pendidikan Karakter melalui Program Pembiasaan Membaca Al-Qur'an. Jurnal Kebijakan Dan Pengembangan Pendidikan, 1(2).

Miles, H., \& Huberman, A. M. Saldana.(2014). Qualitative data analysis: A methods sourcebook, 3 .

Mudzanatun, Suyitno, Putri, A. D. S. \& Artharina, F. P. (2018). Analisis Minat Baca Mahasiswa PGSD UPGRIS Semester 5 Pada Mata Kuliah Kajian Kurikulum Bahasa Indonesia. Laporan Penelitan Dosen Pemula. Semarang: Universitas PGRI Semarang

Muslih, M. (2016). Pengaruh Lingkungan Keluarga dan Lingkungan Sekolah Terhadap Prestasi Belajar Siswa Kelas 6 SD N Limbangan. Jurnal Ilmiah Indonesia. 1(4): 4150. 
Nitte, Y., \& Bulu, V. (2020). Pemetaan Implementasi Pendidikan Karakter di Sekolah Dasar se-Kota Kupang. Jurnal Kependidikan: Jurnal Hasil Penelitian dan Kajian Kepustakaan di Bidang Pendidikan, Pengajaran dan Pembelajaran, 6(1), 38-47. doi:https://doi.org/10.33394/jk.v6i1.2326

Noor, K. B. M. (2008). Case study; A strategic research methodology. American Journal of Applied Sciences, 5(11), 1602-1604.

Peraturan Menteri Pendidikan dan Kebudayaan RI Nomor 23 Tahun 2015 tentang Penumbuhan Budi Pekerti

Perpustakaan, D. B. (2014). Grand Design Pembudayaan Kegemaran Membaca. Jakarta: Perpustakaan Nasional RI

Pitaloka, P. (2018). Memupuk Minat Baca Anak. Jurnal Iqra. 12(2): 26-36.

Purnomo, A. R. P. (2018). Cerita Rakyat Jepang. Surabaya: Airlangga University Press

Ramdhani, M. A. (2017). Lingkungan pendidikan dalam implementasi pendidikan karakter. Jurnal Pendidikan UNIGA, 8(1), 28-37.

Sari, P. (2018). Penanaman Nilai Karakter Gemar Membaca. Jurnal Raushan Fikr. 7(2). 205217

Sari Wijayanti, T. (2018). Penerapan Terapi Cobra untuk Merubah Karakter Siswa SMAN 7 Mataram. Jurnal Kependidikan: Jurnal Hasil Penelitian dan Kajian Kepustakaan di Bidang Pendidikan, Pengajaran dan Pembelajaran, 4(2), 206-214. doi:https://doi.org/10.33394/jk.v4i2.1132

Satgas GLS Kemendikbud. (2018). Desain Induk Gerakan Literasi Sekolah. Jakarta: Direktorat Jendral Pendidikan Dasar dan Menengah Kementerian Pendidikan dan Kebudayaan

Satgas GLS Kemendikbud. (2018). Strategi Literasi Dalam Pembelajaran di Sekolah Menengah Pertama. Jakarta: Direktorat Jendral Pendidikan Dasar dan Menengah Kementerian Pendidikan dan Kebudayaan

Sobirin, M. \& Susapti, P. (2018). Cultural Literacy Building of Primary School Students as Basic Concept. Mudarrisa: Jurnal Kajian Pendidikan Islam. 10(2): 206-221

Soemanto, P. P. (2003). Landasan Kerja Pemimpin Pendidikan. Cet. IV,(Jakarta: Rineka Cipta.

Solihin, L., Hijriani, I., Raziqiin, K., Zaenuri, M. (2019). Indeks Aktivitas Literasi Membaca 34 Provinsi. Jakarta: Pusat Penelitian Kebijakan Pendidikan dan Kebudayaan, Badan Penelitian dan Pengembangan, Kementerian Pendidikan dan Kebudayaan

Sugiyono. (2015). Metode Penelitian Pendidikan. Bandung: Alfabeta

Sumarsih, S., \& Zakaria, Z. (2020). Implementation Of Character Education Program In Vocational School, Lebong District. International Journal of Educational Management and Innovation, 1(3), 238-244.

Suyatno, Jumintono, Pambudi, D. I., Mardati, A., Wantini. (2019). Strategy of Values Education in the Indonesian Education System. International Journal of Construction. 12(1): 607-624

Syahrul, A. R. (2017). Reward, Punishment Terhadap Hasil Belajar Siswa IPS Terpadu Kelas VIII MTsN Punggasan. Jurnal Curricula. 2(1): 1-9

Teguh, M. (2020). Gerakan literasi sekolah dasar. Jurnal Pendidikan Dasar Flobamorata, 1(2), 1-9.

Undang-Undang RI Nomor 20 tahun 2003 tentang Sistem Pendidikan Nasional

Wening, M. H., \& Hasanah, E. (2020). Strategies For Developing Religious Culture To Shape The Character of Students. International Journal of Educational Management and Innovation, 1(3), 262-270. 
Yaumi, M. (2014). Pendidikan Karakter. Jakarta: Prenada Media Group.

Yin, R. K. (2006). Case study methods. In In: J.L. Green, G. Camilli, \& P. B. Elmore (Eds.), Handbook of complementary methods on educational research. (pp. 111-122). American Educational Research Association.

Zulfahita, Z., Husna, N., \& Mulyani, S. (2020). Kemampuan Literasi dan Kepercayaan Diri Siswa SMP Berdasarkan Akreditasi Sekolah Swasta dan Negeri di Kota Singkawang. Jurnal Kependidikan: Jurnal Hasil Penelitian dan Kajian Kepustakaan di Bidang Pendidikan, Pengajaran dan Pembelajaran, 6(3), 407-421. doi:https://doi.org/10.33394/jk.v6i3.2806 